\title{
Possible Routes of Transmission and Precautions to be taken in Dental Practice from the Most Unwanted Evil COVID-19- A Review
}

SRIVIDYA ATHKURI', UDAYARAMYA SALAGALLA², RAVICHANDRA RAVI',

ROOPESH BORUGADDA ${ }^{4}$, CHARISHMA CHOWDARY PONUGUBATI ${ }^{5}$

(cc) EY-NC-ND

\section{ABSTRACT}

Nosocomial infections are responsible for thousands of deaths worldwide every year which occur mainly because of virus exposure. One of such kind of infectious disease that has recently caused an outbreak is COVID-19 and a novel corona virus was its causative agent. It was declared as pandemic and emergency of international concern by WHO. Among the health care professions, dentistry has high risk of microbial infections either by direct/indirect contact or by atmospheric transmission. In order to limit the effects of virus diffusion infection control is an important step. Data was collected from electronic databases like PubMed, Medline, Scopus by entering the key words and all the relevant articles were collected and reviewed. The present review highlights the importance of preventing the virus transmission by possible methods of infection control procedures which should be followed during every step of a treatment procedure in a clinical practice.

Keywords: Coronavirus disease, Disease transmission, Infection control, Severe acute respiratory syndrome-Coronavirus 2

\section{INTRODUCTION}

Severe Acute Respiratory Syndrome- Coronavirus 2 (SARSCoV-2) is the present global health concern which causes severe respiratory tract infections in humans and a novel corona virus was said to be its causative pathogen [1]. In previous years SARS-CoV and Middle East respiratory syndrome (MERSCoV) were found to be similar in origin as with SARS-CoV-2 which is zoonotic, with Chinese (Rhinolophussinicus) being the most probable origin. Researchers indicate that, there was a single animal-to-human transmission of COVID-19 and then the transmission is from human-to-human which caused an outbreak [2].

Globally, till $13^{\text {th }}$ June 2020 there were $75,53,182$ confirmed cases and 4,23,349 deaths. Among the established cases 1.03:1 was found to be male to female (sex ratio), and the median age is 51 , the median age for males is 52 (IQR 37-65) years, and for females 50 (IQR 35-64) years [3].

The transmission is mainly through the contact with droplets from talking, coughing, sneezing (related to human respiratory activities), and aerosols generated during clinical procedures. During dental procedures, there will be production of aerosols and airborne particles especially when treating symptomatic COVID-19 patients where dentists are directly and closely exposed to the virus. Therefore, dentists should focus mainly on prevention of COVID19 infection by following proper infection control procedures during each and every step of the treatment procedure [4].

\section{Possible Transmission Routes of COVID-19 in Dental Clinics}

Along with symptomatic patients of COVID-19, asymptomatic patients and patients in incubation period are also found to be the carriers of SARS-CoV-2 $[5,6]$. On an average the incubation period of COVID-19 is of 5 to 6 days but some evidences suggest that it could be as long as 14 days $[7,8]$. The risk of being infected is higher in the closed spaces due to the elevated aerosol concentrations.
SARS-CoV-2 has a replication number of 2.2 i.e., one infected patient can easily infect two other persons [9].

Individuals who are in close contact to an infected person with in radius of $6 \mathrm{ft}$ can be easily infected through aerosols generated by coughing and sneezing. In-order to minimise this, social distancing was recommended. If droplets of SARS-CoV-2 are present on the inanimate objects produced by the infected person, they can be transmitted to other individuals by touching these surfaces. On an average a person touches his/her face for 23 times per hour, which contributes to $44 \%$ of these occurrences involving mucous membranes of the mouth and nose. This indicates that nosocomial spread of COVID-19 in dental office setting can occur via aerosol, fomites or the feco-oral route [10].

The 2019 nCoV enters the cell through Angiotensin-Converting Enzyme 2 (ACE-2) cell receptor similar to SARS-CoV, which uses ACE2 as a receptor to invade cells, causing human-to-human transmission. As the dental procedures involves exposure to saliva, blood and other body fluids, use of sharp instruments, face to face communication with patients, there will be high risk of the COVID19 infection. In dental settings, the pathogenic microorganisms can be transmitted by inhalation of airborne pathogens which remains suspended for longer periods in air, and microorganisms via droplets and aerosols generated from an infected individual that can be pushed by cough to a relatively small distance [11]. In dental clinics how the 2019 nCov spread is shown in [Table/Fig-1].

\section{PRECAUTIONS TO BE TAKEN IN A CLINICAL PRACTICE}

\section{Patient Evaluation and History}

The dental activities during the time of COVID-19 should be restricted to the procedures that cannot be postponed. There are 4 crucial phases such as patient triage, patient's entrance into the practice, dental treatment and after-treatment management. 


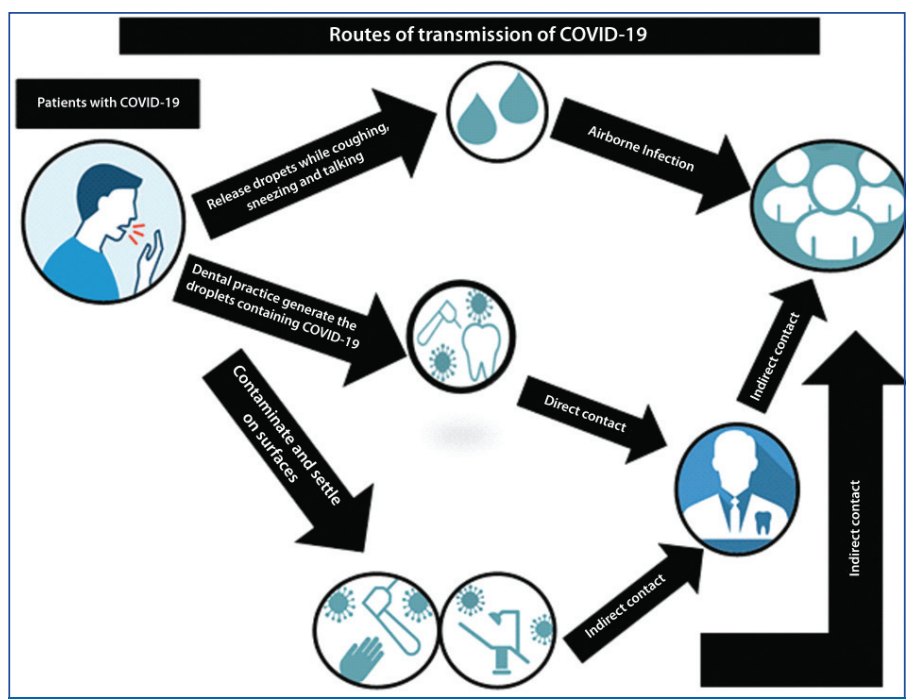

[Table/Fig-1]: Routes of transmission of 2019 nCoV in Dental Clinics \& Hospitals.

Potentially, 4 types of patients may be presenting dental emergencies:

1. Subjects with known SARS-CoV-2 infection,

2. Subjects at potential risk of infection,

3. Subjects with unknown risk of infection, and

4. Subjects who have healed from COVID-19.

Due to the presence of the virus despite of the absence of the clinical manifestations, every patient who appears healthy should however be regarded at unknown risk of being contagious $[5,6,12]$.

If the patient infected with COVID-19 visits the dental clinic, the dentist should be able to identify the patient with COVID19 infection, and immediately should inform to the infection control department and quarantine the patient, particularly in the pandemic period of nCoV-2019. Body temperature should be measured with contact free forehead thermometer followed by the questionnaire.

\section{Questionnaire for patients}

1. Do you have fever within the past 14 days?

2. Have you experienced a recent attack of respiratory problems i.e., cough or difficulty in breathing within the past 14 days?

3. In past 14 days have you or any household member travelled to an area with high incidence of COVID-19 transmission?

4. In the past 14 days have you or any household member had contact with a patient with confirmed COVID-19 infection? [10]

\section{Patient Cohorting}

If patient's body temperature is below $37.3^{\circ} \mathrm{C}$ and has positive answers for the questionnaire, treatment can be deferred till 14 days after the exposure. It was asked by the patients to be self -quarantine and if any symptoms related to flu, or fever is noticed, then immediately report to the local health authority.

If patient's body temperature is not less than $37.3^{\circ} \mathrm{C}$ and positive reply with any of the screening questions, he/she should be immediately quarantined and should be informed to local legal authorities. If patient's body temperature is below $37^{\circ} \mathrm{C}$, with negative reply to all the screening questions, then the patient can be treated with extra protection measures and aerosol procedures should be minimised as possible. If patient's body temperature is not less than $37.3^{\circ} \mathrm{C}$ with negative response to all the screening questions, he/she should be instructed with further medical care $[10,11]$.

\section{Patient Waiting Area and Oral Examination}

In the patient waiting area, it is recommended to keep the distance of at-least $1 \mathrm{~m}$ between chairs and long-time of waiting should be avoided. Patients should be advised to remove all the potentially contaminated objects like clothing, bags, and mobiles in the waiting room. Proper ventilation should be maintained in the waiting area and disinfection should be done regularly. It is advised to the subjects who were accompanying the patient that they should wait outside the dental clinic. There should be not more than one patient in the waiting room.

In the examination area, minimum distance of 3 metres, should be maintained between dental chairs. Patient and operator should wear all the protective equipment. Instruments used for examination must be cleaned with detergent, autoclave, and must be stored in covered pack or container. All surfaces that may be touched by the patients should be disinfected with sodium hypochlorite $0.1 \%$ or $70 \%$ isopropyl alcohol. Use of disposable instruments like mouth mirrors will be more helpful in prevention of infection. All dental instruments necessary for the treatment should be prepared in advance to limit contamination and make the procedure faster [12].

\section{Radiographs}

There is a chance of spread of infection due to the gag or cough reflex that may occur during the intraoral imaging. As an alternative to the intraoral imaging for preventing contamination, panoramic radiography or cone-beam computed tomographic imaging can be used. For intraoral imaging, use of double barrier can prevent perforation to sensors [10].

\section{Hand Hygiene}

Practicing proper hand hygiene is important because of the transmission of the 2019-nCoV through the feco-oral route. A two-before and three-after hand hygiene guideline is proposed by the infection control department of the West China Hospital of Stomatology, Sichuam University, to reinforce the compliance of hand washing. Specifically, the oral professionals should wash their hands before patient examination, before dental procedure, after touching the patient, after touching the surroundings and equipment without disinfection, and after touching the oral cavity, ruptured skin or wound, blood, fluid secretion, and excrement. Hand disinfection is suggested even for patients [11].

\section{Personal Protective Measures for Operator and Assistants}

Protection of eyes, oral and nasal mucosa with the protective equipment like gloves, masks, protective outerwear, protective surgical glasses, and shields can be more useful as transmission of SARS CoV-2 is mainly through airborne droplets [2].

For dental professionals three-level protective measures are endorsed for specific situations.

1. Primary protection is the standard protection advised for clinical staff as they should wear Working clothes (white coat), disposable working cap, disposable surgical mask, along with protective goggles or face shield, and disposable nitrile gloves or latex gloves.

2. Secondary protection is the advanced protection for dental professionals, they should wear Working clothes (white coat) with disposable isolation clothing or surgical clothes outside, disposable head cap, disposable surgical mask, protective goggles, face shield, and disposable latex gloves.

3. If any dental professional comes in contact with patient suspected or confirmed 2019-nCoV infection, then Tertiary protection is recommended which is strengthened protection [11].

If working distance is less than 1 meter from patient for non-aerosol generating procedure, use of surgical or procedural mask should be used at minimum. For aerosol generating procedures (using high-speed handpiece, air-water syringe, and ultrasonic scaler), a particulate respirator that is at least as protective as a National Institute for Occupational Safety and Health (NIOSH)-certified N95, 
European Standard Filtering Face Piece 2 (EU FFP2), or equivalent should be used. To execute an emergency dental treatment with alleged CoV-19 case, an advanced level of respiratory guard should be considered, such as EU FFP3 respirators conforming to European Standard 149 (EN149) [13]. Centers for Disease Control and Prevention recommendations should be followed for putting on and removing personal protective equipment for treating COVID-19 patients [14].

\section{Mouth Rinse before Dental Procedure}

Oxidative agents like $1 \%$ hydrogen peroxide or $0.2 \%$ povidone can be used as pre-procedural mouth rinse as $2019 \mathrm{n}$ CoV is susceptible to oxidation and they also reduce the microbial salivary load in the oral cavity. These pre-procedural mouthrinses are more useful in cases of procedures where rubber dam application is not possible [11].

\section{Reduction of Aerosol Production Rubber dam application}

Saliva and blood contaminated aerosol or spatters which were produced in the dental setting with the use of high speed hand pieces and dental ultrasonic devices is minimised with the rubber dam application. Samarnayake LP et al., reported that the application of rubber dam could considerably diminish airborne particles in 3-foot diameter of the operational field by $70 \%$ [15]. The use of high velocity suction and rubber dams is advised to reduce the rotary generated aerosols during dental procedures $[15,16]$. It also improves the quality of treatment.

\section{Anti-retraction hand piece}

During the dental treatments, the high levels of debris and fluid will be aspirated with the use of high-speed hand piece without anti-retraction valves [11]. The study by $\mathrm{Hu} \mathrm{T}$ et al., showed that back flow of oral bacteria and HBV into the tubes of the handpiece and dental unit has been reduced significantly with the use of antiretraction high-speed dental handpiece, when compared with the handpiece without anti-retraction function [17].

\section{Removal or filter of contaminated air by HEPA and HVE}

There are several methods to remove/filter contaminated air in treatment areas; the two most commonly used devices include the inexpensive High-Volume Evacuator (HVE) and the expensive High-Efficiency Particulate Arrestor (HEPA) filters. HVE filter: It is a device which works on suction and it removes air at a rate of up to $2.83 \mathrm{~m}^{3}$ per minute. As soon as the aerosols are generated it removes it and it efficiently reduces the infection at operative site by $90 \%$. [18]. It is advised that the device should be at a distance of approximately 6-15 $\mathrm{mm}$ from the active ultrasonic tip. Modified HEPA filters can reduce $99.97 \%$ of the aerosol particles $0.3 \mu \mathrm{m}$ in diameter. The retained microbes in the filter may proliferate and become the source of infection is the disadvantage of the filter [19]. In addition, soiled HEPA filters are difficult to clean and expensive to replace $[13,20]$. When subjected to sustained ultraviolet irradiation - UVGI - the DNA of all bacteria and viruses are ruptured thus rendering them sterile and incapable of reproduction [21]. In every dental specialisation, there are some precautions which can reduce droplet generation [Table/Fig-2] [13,22,23].

\section{DISINFECTION OF THE CLINICAL SETTINGS}

In order to limit the contamination it is advised that all the dental instruments should be kept handy in advance. To avoid direct contamination, the working surfaces, the dental chair and devices are covered with disposable protections.

Effective measure for reducing the risk of exposure to health care workers and patients is the disinfection of hospital surfaces. Appropriate disinfection of contaminated surfaces and equipment is crucial in interrupting the spread of viruses such as SARS CoV [24]. Surface disinfection procedures with $62-71 \%$ ethanol, $0.5 \%$

\begin{tabular}{|l|l|}
\hline Dental discipline & \multicolumn{1}{c|}{ Special precaution } \\
\hline Endodontics & $\begin{array}{l}\text { - Application of rubber dam during endodontic treatment. } \\
\text { - To reduce the fomite transmission of the COVID-19 the } \\
\text { minimised. }\end{array}$ \\
\hline $\begin{array}{l}\text { Restorative and } \\
\text { Pedodontics }\end{array}$ & $\begin{array}{l}\text { - Avoid rotary instruments for cavity preparation. In } \\
\text { selective cases, consider using chemomechanical caries } \\
\text { removal or atraumatic restorative techniques. }\end{array}$ \\
\hline Periodontics & $\begin{array}{l}\text { - Manual scaling and polishing are practiced to reduce the } \\
\text { aerosols [22] }\end{array}$ \\
\hline [13,22,23]. & $\begin{array}{l}\text { - Salivary suction must be performed with care to avoid } \\
\text { gagging } \\
\text { - Select and adjust trays to the right size for impression } \\
\text { making to avoid cough reflex. For highly selective patients, } \\
\text { consider applying oral mucosa anaesthesia to the throat } \\
\text { before impression making. } \\
\text { - Rubber dam usage during FPD or single crown } \\
\text { preparation by either placing supragingival finish line or } \\
\text { splitdam technique [23] } \\
\text { - Touching other objects in the dental office to be avoided } \\
\text { during the RPD and FPD try-in inorder to prevent saliva } \\
\text { contamination } \\
\text { - The dental prosthesis, impressions, and other } \\
\text { prosthodontic materials after removal from the oral cavity } \\
\text { should be thoroughly disinfected using the intermediate } \\
\text { level disinfectant. }\end{array}$ \\
\hline $\begin{array}{l}\text { Oral and Maxillofacial } \\
\text { Surgery }\end{array}$ \\
supine position to circumvent working in the breath way.
\end{tabular}

hydrogen peroxide or $0.1 \%$ sodium hypochlorite significantly reduces coronavirus infectivity on surfaces within one minute exposure time. The persistence of corona viruses on different types of inanimate surfaces is represented in [Table/Fig-3] [1].

\begin{tabular}{|l|c|c|}
\hline Type of surface & Virus & Persistence \\
\hline Steel & MERS-CoV & $48 \mathrm{hr}$ \\
\hline Aluminium & HCoV & $2-8 \mathrm{hr}$ \\
\hline Metal & SARS-CoV & 5 days \\
\hline Wood & SARS-CoV & 4 days \\
\hline Paper & SARS-CoV & $4-5$ days \\
\hline Glass & SARS-CoV & 4 days \\
\hline Plastic & SARS-CoV & $\leq 5$ days \\
\hline PVC & HCoV & 5 days \\
\hline Silicon rubber & HCoV & 5 days \\
\hline Surgical glove (latex) & HCoV & $\leq 8 \mathrm{hr}$ \\
\hline Disposable gown & SARS-CoV & 24 hr \\
\hline Ceramic & HCoV & 5 days \\
\hline Teflon & HCoV & 5 days \\
\hline $\begin{array}{l}\text { [Table/Fig-3]: Persistence of coronaviruses on different types of inanimate } \\
\text { HCoV: Human Coronavirus NL63 }\end{array}$ & & \\
\hline
\end{tabular}

\section{Recommended Disinfection and Sterilisation Protocols for Dental Clinics while Treating Patients during COVID-19 Pandemic} Treatment area/patient care area

- All critical, heat resistant semi-critical instruments and handpieces should be cleaned and sterilised after each use or discarded.

- Heat sensitive semi-critical items can be processed with highlevel disinfection e.g., 2\% Gluteraldehyde.

- High touch/clinical surfaces that are difficult to clean must be covered using a physical barrier for every patient or disinfected between patients. (e.g., 1\% Sodium hypochlorite or $70 \%$ alcohol)

- Use moistened wipe/cloth to clean all surfaces with freshly prepared disinfectant solution. (e.g., 1\% Sodium hypochlorite or $3 \%$ hydrogen peroxide). Always Discard remnant diluted solution 
- $\quad$ Floor-Use Wet Moping- Multibucket

\section{Technique:}

1. Water followed by

2. Detergent followed by

3. Low Level Disinfectant like 3\% hydrogen peroxide, $1 \%$ Sodium hypochlorite or EPA approved agents

- Mop heads and cleaning cloths must be decontaminated regularly by Laundering (heat disinfection) with detergent and drying at $80^{\circ} \mathrm{C}$ and changed frequently

- Disinfectant fogging was not advised.

\section{Reception and patient waiting area}

- Avoid sweeping with broom

- Use wet moping with warm water and detergent or hospital disinfectant (e.g., 1\% Sodium hypochlorite).

- High touch surfaces must be cleaned more frequently with detergent/disinfectant [25].

Infection Control Measures for Non-Autoclavable Patient Care Items (NAPCl) are tabulated in [Table/Fig-4] [26].

\begin{tabular}{|c|c|c|}
\hline $\mathrm{NAPCl}$ & $\begin{array}{l}\text { Means to prevent } \\
\text { or manage con- } \\
\text { tamination }\end{array}$ & $\begin{array}{l}\text { Intermediate level } \\
\text { disinfection }\end{array}$ \\
\hline Shade guide & $\begin{array}{l}\text { Barrier/avoid } \\
\text { touching patients } \\
\text { mouth }\end{array}$ & $\begin{array}{l}\text { Immersion in } 70-80 \% \\
\text { alcohol for } 10 \mathrm{~min}\end{array}$ \\
\hline $\begin{array}{l}\text { Alginate mixing spatula } \\
\text { Wire cutter }\end{array}$ & \multirow{2}{*}{$\begin{array}{l}\text { Barrier/use other } \\
\text { autoclavable } \\
\text { instruments }\end{array}$} & $\begin{array}{l}\text { Immersion in } 70-80 \% \\
\text { alcohol for } 10 \mathrm{~min}\end{array}$ \\
\hline X-ray tube and lead apron & & $\begin{array}{l}\text { Soak-wipe-soak with } \\
0.5 \% \mathrm{NaOCl}\end{array}$ \\
\hline $\begin{array}{l}\text { Impression materials (alginate, ZOE) } \\
\text { Stone casts, wax, special trays } \\
\text { Removable orthodontic appliances } \\
\text { Acrylic dentures, cobalt chromium } \\
\text { dentures } \\
\text { Crown and bridge works }\end{array}$ & $\mathrm{N} / \mathrm{A}$ & $\begin{array}{l}\text { Immersion in } 0.5 \% \\
\mathrm{NaOCl} \text { for } 10 \mathrm{~min} \text {. }\end{array}$ \\
\hline X-ray packets (paper) & $\begin{array}{l}\text { Barrier or use dark } \\
\text { room technique }\end{array}$ & $\begin{array}{l}\text { Immersion in } 0.5 \% \\
\mathrm{NaOCl} \text { or } 70-80 \% \\
\text { alcohol for } 10 \mathrm{~min}\end{array}$ \\
\hline \multicolumn{3}{|c|}{$\begin{array}{l}\text { [Table/Fig-4]: Infection control measures for non-autoclavable patient care items [26]. } \\
\text { The best way is to prevent contamination. Pre-cleaning process is most important and Intermedi- } \\
\text { ate level disinfection is last resort [26] }\end{array}$} \\
\hline
\end{tabular}

\section{Dental Water Line Disinfection}

After each patient the hand pieces, ultrasonic scalers, air/water syringes should be operated for a minimum of 20-30 seconds to flush out the material that might have entered the air/water lines [27].

Flushing only reduces the microbial content in the dental water. Biofilms which are adherent to the inner walls of the dental unit water lines were not removed by flushing. Therefore, the adherent biofilms in the dental unit water lines contaminate the incoming water. Disinfectant solutions like chlorhexidine gluconate, hydrogen peroxide, povidone-iodine, Hypochlorous acid can be used in dental unit water lines to remove the biofilms. In-addition to this, it is essential to have good source of water and use of anti-retraction Valves to maintain the germ free environment [28].

\section{MANAGEMENT OF WASTE}

The health care should be disposed safely by assigning responsibility and sufficient human and material resources to manage the waste. During amid times of SARS CoV-19 health care waste should be collected in designated containers and bags, treated and then safely disposed of or treated, or both, mostly on the spot. All health care workers who deals with waste should wear personal protective equipment like (shoe cover, long sleeved gown, mask and goggles/face shield), hand hygiene should be performed after removing it $[29,30]$.

\section{CONCLUSION(S)}

Unlike other professions, Dentistry has a unique way of working environment which requires close contact between operator and patient and with production of aerosols leading to high risk of exposure to many infectious diseases like COVID-19. Therefore, knowing not only the signs and symptoms of any disease, possible ways of contamination and disease transmission and taking necessary precautions like infection control procedures may help in preventing many transmissible diseases like SARS CoV-19. Further prospective assessment of the implications of COVID-19 outbreak in dental practice may help in its prevention.

\section{REFERENCES}

[1] Kampf G, Todt D, Pfaender S, Steinmann E. Persistence of coronaviruses on inanimate surfaces and their inactivation with biocidal agents. J Hosp Infect. 2020;104(3):246-51.

[2] Meng L, Hua F, Bian Z. Coronavirus disease 2019 (COVID-19): emerging and future challenges for dental and oral medicine. J Dent Res. 2020;99(5):481-87.

[3] Coronavirus disease 2019 (COVID-19) Situation Report (WHO) -145 data as reported by the national authorities by 10:00 CET 06/13/2020.

[4] Sabino-Silva R, Jardim AC, Siqueira WL. Coronavirus COVID-19 impacts to dentistry and potential salivary diagnosis. Clin Oral Investig. 2020;24(4):1619-21.

[5] Chan JF, Yuan S, Kok KH, To KK, Chu H, Yang J, et al. A familial cluster of pneumonia associated with the 2019 novel coronavirus indicating person-to-person transmission: a study of a family cluster. The Lancet. 2020;395(10223):514-23.

[6] Rothe C, Schunk M, Sothmann P, Bretzel G, Froeschl G, Wallrauch C, et al. Transmission of 2019-nCoV infection from an asymptomatic contact in Germany. N Engl J Med. 2020;382(10):970-71.

[7] Backer JA, Klinkenberg D, Wallinga J. Incubation period of 2019 nove coronavirus (2019-nCoV) infections among travellers from Wuhan, China, 20-28 January 2020. Euro Surveill. 2020;25(5):2000062.

[8] Li Q, Guan X, Wu P, Wang X, Zhou L, Tong Y, et al. Early transmission dynamics in Wuhan, China, of novel coronavirus-infected pneumonia. N Engl J Med. 2020;382(13):1199-207.

[9] Ravi R. Covid-2019: A Microbiological Monster. Asian J Med and Health. 2020; 18(2):52-57.

[10] Ather A, Patel B, Ruparel NB, Diogenes A, Hargreaves KM. Coronavirus Disease 19 (COVID-19): Implications for clinical dental care. J Endod. 2020;46(5):584-95.

[11] Peng X, Xu X, Li Y, Cheng L, Zhou X, Ren B. Transmission routes of 2019-nCoV and controls in dental practice. Int J Oral Sci. 2020;12(1):1-6.

[12] Izzetti R, Nisi M, Gabriele M, Graziani F. COVID-19 transmission in dental practice: brief review of preventive measures in Italy. J Dent Res. 2020:0022034520920580.

[13] Ge ZY, Yang LM, Xia JJ, Fu XH, Zhang YZ. Possible aerosol transmission of COVID-19 and special precautions in dentistry. J Zhejiang Univ-Sci B. 2020: 21(5): 361-68.

[14] https:// www.cdc.gov/hai/pdfs/ppe/ppe-sequence.pdf. Site accessed April 29 2020.

[15] Samaranayake LP, Reid J, Evans D. The efficacy of rubber dam isolation in reducing atmospheric bacterial contamination. ASDC J Dent Child 1989;56(6):442-44.

[16] Kohn WG, Collins AS, Cleveland JL, Harte JA, Eklund KJ, Malvitz DM. Guidelines for infection control in dental health-care settings-2003J Am Dent Assoc. 2004;135(1):33-47.

[17] Hu T, Li G, Zuo Y, Zhou X. Risk of hepatitis B virus transmission via dental handpieces and evaluation of an antisuction device for prevention of transmission. Infect Control Hosp Epidemiol. 2007;28(1):80-82

[18] Narayana TV, Mohanty L, Sreenath G, Vidhyadhari P. Role of preprocedural rinse and high volume evacuator in reducing bacterial contamination in bioaerosols. J Oral Maxillofac Pathol. 2016;20(1):59-65.

[19] Chuaybamroong P, Chotigawin R, Supothina S, Sribenjalux P, Larpkiattaworn S, Wu CY. Efficacy of photocatalytic HEPA filter on microorganism removal. Indoor Air. 2010;20(3):246-54.

[20] Day DB, Xiang J, Mo J, Clyde MA, Weschler CJ, Li F, et al. Combined use of an electrostatic precipitator and a high-efficiency particulate air filter in building ventilation systems: Effects on cardio-respiratory health indicators in healthy adults. Indoor Air. 2018;28(3):360-72.

[21] Ward KA. Airborne contamination in dentistry. Int Dent SA. 2006;9(1):62-65.

[22] Krishna R, De Stefano JA. Ultrasonic vs. hand instrumentation in periodontal therapy: clinical outcomes. Periodontology 2000. 2016;71(1):113-27.

[23] Li RWK, Leung KWC, Sun FCS, Samaranayake LP. Severe acute respiratory syndrome (SARS) and the GDP. Part II: implications for GDPs. Br Dent J. 2004;197(3):130-34

[24] Hulkower RL, Casanova LM, Rutala WA, Weber DJ, Sobsey MD. Inactivation of surrogate coronaviruses on hard surfaces by health care germicides. Am J Infect Control. 2011;39(5):401-07.

[25] https://www.epa.gov/pesticideregistration/list-n-disinfectants-use-against-sarscov-2 LAST UPDATED ON MARCH 13, 2020. 
[26] The basic protocol- Infection control guide lines of the dental service, Department of health (2019).

[27] Porteous N. Dental unit waterline contamination--a review. Texas Dent J. 2010;127(7):677-85.

[28] Shajahan IF, Kandaswamy D, Srikanth P, Narayana LL, Selvarajan R. Dental unit waterlines disinfection using hypochlorous acid-based disinfectant. J Conserv Dent. 2016;19(4):347.
[29] World Health Organization. Water, sanitation, hygiene, and waste management for the COVID-19 virus: interim guidance, 23 April 2020. World Health Organization; 2020.

[30] Dhar A, Sridharan G. Biomedical waste management in dental Clinics-a review: SSRG-Int J Med Sci. 2018;5(5):01-03.

\section{PARTICULARS OF CONTRIBUTORS:}

1. Assistant Professor, Department of Conservative Dentistry and Endodontics, GSL Dental college and Hospital, Rajahmundry, Andhra Pradesh, India

2. Assistant Professor, Department of Conservative Dentistry and Endodontics, Saint Joseph Dental College and Hospital, Eluru, Andhra Pradesh, India.

3. Associate Professor, Department of Conservative Dentistry and Endodontics, GITAM Dental College and Hospital, Visakhapatnam, Andhra Pradesh, India.

4. Associate Professor, Department of Conservative Dentistry and Endodontics, GITAM Dental College and Hospital, Visakhapatnam, Andhra Pradesh, India.

5. Postgraduate, Department of Periodontics and Oral Implantology, GITAM Dental College and Hospital, Visakhapatnam, Andhra Pradesh, India.

\section{NAME, ADDRESS, E-MAIL ID OF THE CORRESPONDING AUTHOR:}

Srividya Athkuri,

Assitant Professor, Department of Conservative Dentistry and Endodontics, GSL

Dental College and Hospital, Rajhmundry, Andhra Pradesh, India.

E-mail: Srividyaathkuri@gmail.com

\section{AUTHOR DECLARATION:}

- Financial or Other Competing Interests: None

- Was Ethics Committee Approval obtained for this study? NA

- Was informed consent obtained from the subjects involved in the study? NA

- For any images presented appropriate consent has been obtained from the subjects. NA
PLAGIARISM CHECKING METHODS: Jain Het al.]

- Plagiarism X-checker: May 11, 2020

- Manual Googling: Jun 12, 2020

- iThenticate Software: Sep 18, 2020 (17\%)

\section{ETYMOLOGY: Author Origin}

Date of Submission: May 09, 2020

Date of Peer Review: Jun 06, 2020

Date of Acceptance: Jun 15, 2020

Date of Publishing: Oct 01, 2020 